\title{
MODEL BLENDED LEARNING UNTUK MENINGKATKAN KEMANDIRIAN BELAJAR DAN DAYA TARIK DALAM PERKULIAHAN
}

\author{
Ch. Ismaniati, Sungkono, dan Dian Wahyuningsih \\ Universitas Negeri Yogyakarta \\ Email: christina_ismaniati@uny.ac.id
}

\begin{abstract}
Abstrak
Penelitian ini bertujuan untuk meningkatkan kemandirian belajar mahasiswa dan daya tarik instruksional perkuliahan menggunakan model blended learning. Penelitian ini menggunakan pendekatan penelitian tindakan kelas. Hasil penelitian menunjukkan bahwa, kemandirian belajar mahasiswa Prodi TP FIP UNY dan daya tarik instruksional perkuliahan Multimedia Pembelajaran meningkat dengan digunakannya model blended learning. Kemandirian belajar mahasiswa semula berada pada kategori sangat kurang dengan persentase 39\%, meningkat pada siklus pertama dengan persentase $60 \%$ yang berada pada kategori rendah, dan kembali meningkat pada siklus kedua dengan persentase $73 \%$ yang berada pada kategori tinggi. Daya tarik instruksional juga mengalami peningkatan, semula berada pada kategori sangat rendah dengan persentase $33 \%$, meningkat pada siklus pertama dengan persentase $61,5 \%$ yang berada pada kategori rendah, dan kembali meningkat pada siklus ketiga menjadi $87,5 \%$ pada kategori sangat tinggi. Peningkatan tersebut diperoleh melalui pengaturan setiap tahap model blended learning dengan mengoptimalkan peran mahasiswa dalam mengelola kegiatan belajarnya. Faktor pembiasaan pemanfaatan e-learning dalam perkuliahan juga membantu meningkatkan kemandirian belajar mahasiswa. Daya tarik instruksional perkuliahan dapat meningkat melalui penggunaan dua bentuk pembelajaran yaitu tatap muka dan online. Penggunaan metode hypertext dalam e-learning juga memiliki kontribusi dalam meningkatkan daya tarik instruksional perkuliahan. Metode hypertext dapat membantu mahasiswa untuk mencari materi yang paling dibutuhkan dalam belajar.
\end{abstract}

Kata kunci: kemandirian belajar, daya tarik instruksional, model blended learning

\section{USING BLENDED LEARNING MODEL TO IMPROVE STUDENT INDEPENDENCE LEARNING AND INSTRUCTIONAL ATTRACTION}

\begin{abstract}
This research aims to increase the student independence learning and instructional attraction using blended learning models. The results are as follows, students independent learning and instructional attraction of Multimedia Learning course are improved with the use of blended learning models. Student independence learning was increase from $39 \%$ up to $60 \%$ in cycle I, and up to $73 \%$ in cycle II. Instructional attraction in Multimedia learning course also increased from $33 \%$ up to $61.5 \%$ in cycle I, and up to $87.5 \%$ in cycle II. This enhancement is obtained by setting of each stage of blended learning models to optimize the role of students in managing their learning activities. Habituation factor for utilization of e-learning in the lecture also help improve student independence learning. Instructional attraction can be increased through the use of two methods of learning that is face-to-face and online learning. The use of hypertext methods in e-learning also has contributed to increasing the instructional attraction. Hypertext methods can help students to find materials that are most needed in the study.
\end{abstract}

Keywords: student independent learning, instructional attraction, blended learning models 


\section{PENDAHULUAN}

Dunia memasuki abad XXI, yaitu suatu era dengan tuntutan yang lebih rumit dan menantang, dan suatu era yang memiliki spesifikasi tertentu yang ternyata sangat besar pengaruhnya terhadap segala aspek kehidupan manusia. Dunia pendidikan mendapatkan sorotan yang sangat tajam berkaitan dengan tuntutan untuk menghasilkan sumber daya manusia (SDM) yang berkualitas yaitu sumber daya manusia yang mampu atau bisa "hidup" atau unggul di era XXI (Degeng, 2000:4). Kompetensi yang harus dimiliki oleh manusia yang disebut unggul antara lain adalah:SDM yang mampu berpikir kreatifproduktif, mampu mengambil keputusan tepat, mampu dalam pemecahan masalah, mampu belajar bagaimana belajar, mampu berkolaborasi, dan mampu dalam pengelolaan diri (Degeng, 2000:5).

Dalam lingkup dunia, kompetensi yang dibutuhkan untuk memasuki kehidupan, terutama dunia kerja di abad XXI pada prinsipnya mencakup skills, knowledge, attitude, values, dan ethics. Proses pembelajaran yang berkualitas dan efektif adalah proses pembelajaran yang mampu menimbulkan prakarsa atau keinginan dan aktivitas belajar secara mandiri atau sering disebut dengan kemandirian belajar mahasiswa sehingga mahasiswa berhasil mencapai tujuan-tujuan belajar dan pembelajaran yang memiliki daya tarik yang tinggi atau berdaya tarik bagi mahasiswa.

Berdasarkan uraian tersebut dapat dijelaskan bahwa untuk menghasilkan SDM yang berkualitas yaitu SDM yang unggul perlu dilaksanakan secara berkualitas dan efektif mengarah pada timbulnya atau berkembangnya prakarsa atau kemandirian belajar mahasiswa dan perkuliahan menimbulkan daya tarik pembelajaran yang tinggi sehingga mahasiswa cenderung untuk ingin terus belajar dan hadir dalam perkuliahan suatu mata kuliah oleh karena proses perkuliahannya yang berkualitas tersebut. Ini berarti bahwa proses pembelajaran yang berkualitas menyebabkan timbul dan berkembangnya daya tarik pembelajaran.

Pada kenyataanya, dalam perkuliahanperkuliahan pada umumnya menunjukkan gejala bahwa kemandirian belajar dan daya tarik pembelajaran suatu mata kuliah pada mahasiswa masih rendah. Gejala ini tampak nyata dalam bentuk mahasiswa selalu cenderung duduk-duduk dan mengobrol tentang hal-hal di luar perkuliahan yang tidak jelas arahnya, jika dosen belum hadir di kelas mahasiswa ramai dan kacau-tidak ada yang diskusi atau membaca tentang materi perkuliahan atau buku-buku referensi, banyak juga yang senang dan gembira bila perkuliahan kosong, dan sejenisnya.

Kondisi tersebut juga terjadi pada perkuliahan mata kuliah Multimedia Pembelajaran. Pada perkuliahan tersebut, sebagian besar mahasiswa (lebih dari 70\%) menunjukkan perilaku tidak mengerjakan tugas praktek yang diberikan setelah perkuliahan selesai, tidak pernah membaca buku yang disarankan dosen sebelum mengikuti perkuliahan, selalu datang terlambat, terlambat mengumpulkan tugas, jika perkuliahan dilakukan di ruang komputer mahasiswa cenderung membuka situs-situs yang tidak sesuai dengan materi yang diajarkan dan situs yang disarankan dosen untuk dibuka dalam rangka memperkaya materi perkuliahan. Hal ini menunjukkan adanya gejala kemandirian belajar dan daya tarik pembelajaran mata kuliah Multimedia Pembelajaran yang rendah. Jika hal ini dibiarkan maka mahasiswa tidak akan dapat mencapai hasil pembelajaran sebagaimana diharapkan, dan pada akhirnya tidak akan tercipta SDM yang unggul dan berkualitas untuk dapat "hidup" di abad XXI sebagaimana diuraikan di awal tulisan ini.

Matakuliah Multimedia Pembelajaran merupakan matakuliah yang penting bagi mahasiswa prodi TP UNY. Melalui matakuliah ini, kompetensi yang harus di- 
kuasai mahasiswa, salah satunya mampu melaksanakan kegiatan pengembangan dalam bidang teknologi pendidikan (FIP UNY, 2009:84). Dari matakuliah tersebut mahasiswa memperoleh teori dan praktek bagaimana merancang, mengembangkan, dan mengevaluasi program Multimedia Pembelajaran sesuai prinsip media pembelajaran dan karakteristik siswa. Matakuliah tersebut pada prakteknya banyak menggunakan teknologi komputer dan internet, sehingga diperlukan suatu model pembelajaran yang dapat mengakomodasi sifat dan karakteristiknya. Di samping itu, perkembangan materi mengenai Multimedia Pembelajaran berjalan sangat cepat, sehingga dibutuhkan sumber belajar yang tidak monoton dan selalu up to date.

Pada prinsipnya matakuliah Multimedia Pembelajaran merupakan matakuliah yang menarik, namun jika pengorganisasian materi dan cara penyampaiannya tidak sesuai dengan karakteristiknya maka daya tarik perkuliahan ini menjadi rendah, seperti yang terjadi dalam perkuliahan tersebut di Prodi TP. Agar matakuliah ini memiliki daya tarik yang tinggi maka pembelajaran perlu diorganisasikan dan disampaikan dengan tepat (Degeng, 1989:175). Dengan materi yang selalu up to date, seharusnya mahasiswa secara mandiri mencari bahan ajar yang relevan untuk memperkaya pengetahuan dan keterampilannya, karena tidak semua materi dan bahan ajar diberikan oleh dosen. Namun, dalam pelaksanaannya mahasiswa hanya menerima materi dari dosen saja, tidak memiliki inisiatif untuk mengeksplorasi materi sendiri. Apabila sejak awal pengorganisasian dan penyampaian materi yang dilakukan oleh dosen tidak menarik, maka kemandirian belajar dan daya tarik perkuliahan Multimedia Pembelajaran menjadi rendah.

Mengacu pada pendapat Allison \& Pegler tentang Model Blended learning, dan teori pembelajaran untuk orang dewasa berdasarkan teori belajar dan pembelajar- an konstruktivistik oleh Knowles, Holton, dan Swanson (2005:136), Martinis Yamin (2012:48), dan hasil-hasil penelitian tentang efektivitas penerapan model Blended learning oleh Elizabeth Nel (2005:15), maka untuk meningkatkan kemandirian belajar dan daya tarik pembelajaran mata kuliah Multimedia Pembelajaran perlu dilakukan peningkatan kualitas pembelajaran melalui penggunaan model Blended learning. Model blended learning merupakan model pembelajaran yang fleksibel karena mengkombinasikan setting pembelajaran synchronous dan asynchronous secara tepat guna untuk mencapai tujuan pembelajaran. Beberapa keuntungan menggunakan model ini adalah dapat mengakomodasi karakteristik matakuliah Multimedia Pembelajaran sehingga daya tarik instruksional perkuliahan menjadi tinggi, dan dapat mengembangkan berbagai keterampilan dan sikap, dalam hal ini kemandirian belajar (Nel, 2005:20). Oleh karena itu, diharapkan dengan penggunaan model blended learning ini dapat meningkatkan kemandirian belajar mahasiswa dan daya tarik instruksional perkuliahan Multimedia Pembelajaran khususnya pada mahasiswa program studi TP FIP UNY.

Kemandirian belajar dijelaskan oleh Yusufhadi Miarso (2007:251) sebagai pengaturan program belajar yang diorganisasikan sedemikian rupa sehingga tiap peserta didik dapat memilih dan menentukan bahan dan kemajuan belajarnya sendiri. Martinis Yamin (2012:141) menjelaskan kemandirian belajar sebagai aktivitas belajar yang bebas menentukan arah, rencana, sumber, dan keputusan untuk mencapai tujuan akademik, tetapi bukan bebas dari aturan keagamaan, aturan negara, aturan adat atau masyarakat. Mandiri bukan berarti belajar sendiri tanpa bantuan orang lain, tetapi belajar dengan inisiatif sendiri baik dengan atau tanpa bantuan orang lain.

Orang yang memiliki kemandirian belajar, mengetahui saat kapan membu- 
tuhkan bantuan dan kapan tidak membutuhkan bantuan orang lain dalam belajar. Konsep kemandirian belajar bertumpu pada prinsip bahwa individu yang belajar akan sampai kepada perolehan hasil belajar (Eti Nurhayati, 2011:141). Oleh karena itu, kemandirian belajar harus dimiliki oleh setiap mahasiswa yang belajar di perguruan tinggi.

Mahasiswa merupakan manusia dewasa, ditinjau dari segi usianya mahasiswa sudah memungkinkan untuk melakukan belajar secara mandiri, tanpa banyak tergantung pada kendali dosen. Selanjutnya, Eti Nurhayati (2011:149) menjelaskan bahwa kemandirian belajar merupakan sikap dan perilaku yang terbentuk akibat rancangan proses belajar yang memandirikan peserta didik, bukan sikap yang datang tiba-tiba tanpa proses belajar. Martinis Yamin (2012:144-148) mengemukakan belajar mandiri akan menjadi mudah, apabila pembelajaran yang dilakukan memenuhi syarat-syarat, seperti: 1) adanya masalah; 2) menghargai pendapat dan keterampilan peserta didik; 3) menumbuhkan motivasi; 4) adanya bimbingan dan latihan; 5) memberikan perhatian dan penghargaan pada peserta didik. Malcolm Knowles (1980:46-49) menyatakan tahapan belajar yang mandiri merupakan siklus aktivitas merencanakan, melakukan apa yang telah direncanakan, menerapkan, dan merefleksikan, lalu menyusun perencanaan lagi, dan seterusnya, hingga kemandirian belajar semakin meningkat.

Berdasarkan penjelasan di atas karakter mahasiswa yang memiliki kemandirian belajar adalah inisiatif, percaya diri, tanggungjawab, dan disiplin. Inisiatif merupakan sikap yang ditunjukan mahasiswa ketika mampu memunculkan gagasan kapan saat tepat untuk belajar dan bagaimana cara terbaik untuk dapat belajar secara efektif. Mahasiswa dikatakan memiliki kepercayaan diri yang baik apabila memiliki kemantapan dalam menentukan kegiatan belajarnya, selain itu, memiliki keyakinan bahwa setiap kegiatan belajar yang telah dilakukan dapat berpengaruh kepada perolehan hasil belajarnya. Yakin bahwa setiap tugas yang bersumber dari usaha dan hasil pemikiran orisinilnya memiliki arti tersendiri, layak untuk disejajarkan dengan milik orang lain, serta layak mendapat apresiasi. Tanggungjawab merupakan sikap bersedia menanggung segala konsekuensi atas apa yang telah dikerjakan. Konsekuensi tersebut melekat ketika mahasiswa merencanakan kegiatan belajar dan sumber belajarnya,waktu belajar, serta tujuan dan hasil belajar. Sikap disiplin dapat terlihat ketika mahasiswa tepat waktu dan dapat menaati aturan dan tata tertib kegiatan belajar dan pembelajaran yang telah ditentukan sendiri atau ditentukan secara bersama-sama.

Daya tarik instruksional dapat diartikan sebagai kemenarikan pengorganisasian dan penyajian pembelajaran. Untuk meningkatkan daya tarik instruksional, diperlukan suatu model pembelajaran yang dapat menyajikan bahan ajar melalui multi sumber dan beragam bentuk yang dapat memfasilitasi karakteristik mahasiswa. Perkuliahan juga penting untuk dapat diakses oleh mahasiswa di mana dan kapan saja. Martinis Yamin (2012:97) menjelaskan, penggunaan model pembelajaran tidak terlepas dari bentuk dan muatan materi dalam suatu bidang studi yang disampaikan kepada peserta didik. Dalam perkuliahan Multimedia Pembelajaran prodi teknologi pendidikan yang materinya terdiri dari teori dan praktek dan sifat matakuliahnya yang berbasis teknologi, sangat diperlukan model/strategi pembelajaran yang tepat. Hal tersebut perlu dilakukan karena suatu pembelajaran dapat kehilangan daya tariknya apabila kualitas pembelajarannya rendah.

Penggunaan model pembelajaran yang tepat mutlak diperlukan untuk mempertahankan dan meningkatkan daya tarik instruksional. Degeng (1989:175) menjelaskan sebagai hasil pengajaran, 
kecenderungan siswa untuk tetap belajar, adalah tanggungjawab pengajaran, bukan tanggungjawab bidang studi. Lebih lanjut Degeng (1989:176) menjelaskan, variabel penting yang dapat digunakan sebagai indikator daya tarik instruksional adalah penghargaan dan keinginan lebih (lebih banyak/lama) yang diperlihatkan oleh peserta didik. Kedua hal tersebut dapat dikaitkan baik pada bidang studi dalam hal ini perkulihan Multimedia Pembelajaran maupun pada pelaksanaan pembelajarannya.

Model blended learning merupakan suatu model pembelajaran yang fleksibel, karena menggunakan setting pembelajaran synchronous dan asynchronous. Melalui penggunaan model blended learning daya tarik instruksional dapat ditingkatkan melalui pengorganisasian materi, tempat, waktu, dan aktivitas yang tepat. Selain beberapa hal tersebut, terdapat hal yang lebih penting yaitu karakteristik matakuliah multimedia yang berbasis teknologi. Dari penjelasan tersebut, dapat disimpulkan bahwa penggunaan model blended learning dapat meningkatkan daya tarik instruksional perkuliahan Multimedia Pembelajaran pada prodi Teknologi Pendidikan UNY.

Cheung \& Hew (2011:1325) menyatakan blended learning merupakan kombinasi antara face to face learning dan online learning. Uwes A. Chaeruman (2011) menjelaskan blended learning sebagai pembelajaran yang mengkombinasikan setting pembelajaran synchronous dan asynchronous secara tepat guna untuk mencapai tujuan pembelajaran. Pembelajaran synchronous adalah kegiatan pembelajaran yang dilakukan pada waktu yang sama dan tempat yang sama ataupun berbeda, sedangkan pembelajaran asynchronous adalah kegiatan pembelajaran yang dilakukan pada waktu dan tempat yang berbeda (Littlejohn dan Pegler, 2007:51-53).

Griffith University (2010:24) menjelaskan langkah pembelajaran model blended learning melalui gambar sebagai berikut:

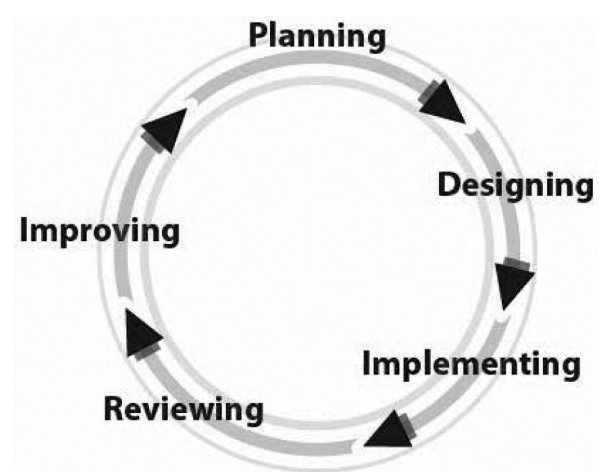

Gambar 1. Langkah Pembelajaran Model Blended learning

Yusufhadi Miyarso (2007:234-235) mengemukakan bahwa kombinasi berbagai pendekatan dalam pembelajaran memungkinkan sumber-sumber virtual dan sumber-sumber fisik bersinergi. Blended learning merupakan pendekatan pedagogik yang mengkombinasi antara efektifitas dengan peluang sosialisasi kelas yang secara teknologi mendorong pembelajaran aktif. Pelaksanaan pendekatan ini memungkinkan sumber belajar online digunakan, terutama yang berbasis web, dengan tanpa meninggalkan kegiatan tatap muka. Dengan pelaksanaan blended learning, pembelajaran berlangsung lebih bermakna karena keragaman sumber belajar yang mungkin diperoleh.

\section{METODE}

Penelitian ini merupakan penelitian tindakan kelas (classroom action research) yang dilaksanakan pada Prodi Teknologi Pendidikan Fakultas Ilmu Pendidikan Universitas Negeri Yogyakarta (TP FIP UNY) pada mata kuliah Pengembangan Multimedia Pembelajaran. Penelitian ini dilaksanakan selama empat bulan dari bulan Juni hingga September 2014. Subjek penelitian ini adalah mahasiswa program studi Teknologi Pendidikan yang menempuh mata kuliah Pengembangan Multimedia Pembelajaran sebanyak 35 mahasiswa. 
Penelitian tindakan kelas ini mengacu pada desain penelitian spiral dari Kemmis \& Mc Taggart (1990:11). Model spiral tersebut berupa tiga langkah kesatuan berulang yaitu plan (perencanaan), act (pelaksanaan tindakan) dan observe (observasi), serta reflect (refleksi).

Prosedur penelitian adalah sebagai berikut: Perencanaan tindakan dilakukan dengan menyusun satuan acara perkuliahan (SAP) tentang materi prinsip teori belajar dalam Multimedia Pembelajaran dengan model blended learning, menyiapkan bahan ajar dalam bentuk tercetak dan digital, menyiapkan e-learning yang digunakan sebagai media pembelajaran online. Pada tahap ini peneliti juga mengkaji dan membahas ulang draft instrument penelitian tentang materi tersebut yang meliputi pedoman pengamatan pelaksanaan pembelajaran dan angket tanggapan mahasiswa. Menyiapkan sarana dan prasarana pembelajaran untuk mendukung pelaksanaan tindakan.

Tahap pelaksanaan siklus pertama perkuliahan dilakukan sesuai dengan syntak pembelajaran model blended learning berdasarkan SAP yang telah dibuat. Pelaksanaan tindakan pada siklus pertama ini dilakukan sebanyak 2 kali perkuliahan tatap muka (face to face learning) dan 2 minggu perkuliahan secara online (online learning). Pada pertemuan pertama perkuliahan tatap muka dosen memfasilitasi mahasiswa dalam mempelajari materi prinsip teori belajar dalam Multimedia Pembelajaran. Selain mendapatkan penjelasan dari dosen mahasiswa dapat memanfaatkan materi dan melaksanaan aktivitas belajar menggunakan e-learning. Pada pertemuan tatap muka kedua, lebih banyak terjadi kegiatan diskusi. Diskusi dilakukan secara berkelompok membahas sub topik contoh penerapan teori belajar dalam Multimedia Pembelajaran. Bahan belajar untuk berdiskusi diusahakan sendiri oleh masing-masing kelompok menggunakan aktivitas online learning yang selanjutnya dipresentasikan pada saat pertemuan tersebut.

Kegiatan pembelajaran online pada minggu pertama dilakukan secara asynchronous melalui kegiatan diskusi pada forum dalam e-learning yang dilakukan baik antara mahasiswa dengan dosen ataupun antar mahasiswa, serta penugasan yang lebih bersifat individu. Pada minggu ini mahasiswa melakukan pengajian materi secara mandiri secara individu dan memanfaatkan materi yang diperlukan melalui e-learning. Pada minggu kedua pembelajaran online masih melakukan kegiatan belajar asynchronous melalui e-learning yang penugasannya secara kelompok, ditambah dengan kegiatan synchronous melalui kegiatan chatting.

Pada tahap ini pula dilakukan pengamatan pada pembelajaran tatap muka untuk mengamati proses perubahan kemandirian belajar yang terjadi. Pada kegiatan pembelajaran online selain mengamati kemandirian belajar mahasiswa melalui e-learning, dapat pula diamati bahan belajar yang disajikan memiliki daya tarik instruksional bagi mahasiswa. Setelah siklus pertama selesai mahasiswa diberikan angket untuk menilai kemandirian belajar yang telah dicapai dan daya tarik instruksional pada materi tersebut. Kemudian data hasil pengamatan dan angket dianalisis dan dilakukan refleksi. Hasil refleksi dijadikan dasar dalam memperbaiki kegiatan perencanaan dan pelaksanaan untuk siklus kedua.

Pada pelaksanaan siklus kedua yang dilaksanakan pada bulan Juli 2014, dilakukan perbaikan berdasarkan refleksi pada siklus pertama. Masih terdapat persamaan dengan siklus pertama kegiatan pembelajaran yang dilakukan pada siklus kedua dilakukan dalam 2 kali pertemuan tatap muka dan 2 minggu kegiatan online learning. Materi yang digunakan pada siklus kedua ini adalah prinsip desain Multimedia Pembelajaran. Selain materi yang berbeda, hal lain yang membedakan antara 
siklus satu dan siklus 2 adalah pada kegiatan belajar yang dilakukan. Pada kegiatan belajar dosen menghadirkan masalah terlebih dahulu sehingga mahasiswa harus mencari penyelesaian masalah sendiri secara berkelompok untuk menyimpulkan fakta mengenai materi yang sedang dipelajari. Peran dosen yaitu memberi motivasi dan bimbingan yang dilakukan baik secara synchronous dan asynchronous. Kegiatan belajaran dalam online learning disusun dengan lebih runtut. Bahan belajar tidak hanya disajikan melalui teks saja, namun menghadirkan video pembelajaran. E-learning yang digunakan untuk melakukan kegiatan pembelajaran online dihubungkan link menuju website yang relevan dengan materi.

\section{HASIL DAN PEMBAHASAN}

Sebelum tindakan diterapkan, mahasiswa diberikan angket awal tentang kemandirian belajar dan daya tarik instruksional mengenai pelaksanaan pembelajaran matakuliah Multimedia Pembelajaran sebelumnya. Hasil angket yang diberikan kepada 35 orang mahasiswa menunjukan bahwa kemandirian belajar memiliki ratarata skor 19 yang berarti kemandirian belajar berada pada kategori sangat rendah dengan persentasi 39\%. Sedangkan hasil angket daya tarik instruksional berada pada kategori sangat rendah dengan rerata skor 16 dan persentase 33\%.

Setelah pelaksanaan perkuliahan dengan menggunakan model blended learning pada siklus pertama yang dilaksanakan pada bulan Juni 2014, kepada subjek penelitian diberikan angket kemandirian belajar pada akhir siklus pertama. Hasil angket siklus pertama menunjukkan bahwa skor rerata angket kemandirian belajar mahasiswa adalah 29 yang masuk pada kategori rendah dengan persetase sebesar $60 \%$. Pada siklus pertama hasil angket daya tarik instruksional menunjukan skor 29,5 yang masuk pada kategori rendah dengan persentase sebesar $61,5 \%$. Data hasil angket siklus pertama kemandirian belajar dapat digambarkan pada tabel 1 , sedangkan daya tarik instruksional digambarkan pada tabel 2 .

Berdasarkan hasil pengamatan pada siklus pertama terlihat aktivitas mahasiswa melakukan browsing di internet mencari bahan tentang materi prinsip teori belajar dalam Multimedia Pembelajaran. Pembelajaran online mulai berjalan dan bahan belajar dalam bentuk digital mulai diperoleh oleh mahasiswa. Namun pelaksanaanya kurang terarah karena instruksi yang diberikan dosen pada siklus ini belum jelas, sehingga mahasiswa terlihat kebingungan. Hal tersebut terli-

Tabel 1. Skor Angket Kemandirian Belajar Siklus 1

\begin{tabular}{lllll}
\hline No & \multicolumn{1}{c}{ Indikator } & Rerata Skor & Persentase & \multicolumn{1}{c}{ Kategori } \\
\hline $\mathbf{1}$ & Inisiatif & 26,8 & $59 \%$ & Rendah \\
$\mathbf{2}$ & Percaya Diri & 28,7 & $61 \%$ & Rendah \\
$\mathbf{3}$ & Tanggungjawab & 28,2 & $60 \%$ & Rendah \\
$\mathbf{4}$ & Disiplin & 29 & $62 \%$ & Rendah \\
\hline & Total Skor & $\mathbf{2 9}$ & $\mathbf{6 0 , 5} \%$ & Rendah \\
\hline
\end{tabular}

Tabel 2. Skor Angket Daya Tarik Instruksional Siklus 1

\begin{tabular}{ccccc}
\hline No & Indikator & Rerata Skor & Persentase & Kategori \\
\hline $\mathbf{1}$ & Penghargaan & 31,2 & $65 \%$ & Tinggi \\
$\mathbf{2}$ & Keinginan Lebih & 27,8 & $58 \%$ & Rendah \\
\hline & Total skor & $\mathbf{2 9 , 5}$ & $\mathbf{6 1 , 5 \%}$ & Rendah \\
\hline
\end{tabular}

Model Blended Learning untuk Meningkatkan Kemandirian Belajar dan Daya Tarik ... 
hat dari banyaknya pertanyaan kepada dosen mengenai hal teknis mengenai penugasan. Peran dosen masih dominan dalam pembelajaran. Terlihat mahasiswa sibuk melakukan diskusi bersama teman namun kurang terarah, karena beberapa kelompok mengumpulkan tugas yang agak melenceng dari materi. Aktivitas pembelajaran online mulai berjalan melalui forum diskusi dan penugasan terstruktur, namun masih banyak mahasiswa yang belum terbiasa. Dalam pengumpulan tugas beberapa masiswa belum tepat waktu pengumpulan sesuai dengan kesepakatan yang telah ditentukan.

Pada siklus kedua setelah dilakukan perbaikan dari siklus pertama baik skor hasil angket kemandirian belajar dan daya tarik instruksional sama-sama meningkat. Hasil angket kemandirian belajar pada siklus ini menunjukan skor 34 yang berada pada kategori tinggi dengan persentase sebesar $73 \%$, sedangkan daya tarik instruksional menunjukan skor 41,85 yang berada pada kategori sangat tinggi dengan persentase sebesar $87,5 \%$. Data hasil angket siklus kedua kemandirian belajar dapat digambarkan pada tabel 3, sedangkan daya tarik instruksional digambarkan pada tabel 4 .

Hasil pengamatan siklus kedua nampak bahwa mahasiswa sudah terbiasa melakukan pembelajaran tatap muka yang dikombinasikan dengan pembelajaran online. Hal tersebut terlihat dari intensitas aktivitas yang dilakukan dalam pembelajaran online. Penugasan dapat berjalan dengan lancar karena instruksi yang diberikan dosen terstruktur dan jelas. Bahan belajar lebih beragam selain berbentuk fisik, bahan berbentuk digital lebih bervariasi sehingga mahasiswa dapat memilih sesuai dengan keinginannya. Terdapat bahan belajar yang dibuat oleh mahasiswa secara berkelompok yang di unggah dalam e-learning sehingga setiap mahasiswa yang memerlukan bahan tersebut dapat mengunduh secara cuma-cuma.

Berdasarkan data di atas dapat dilihat bahwa telah terjadi peningkatan kemandirian belajar dan daya tarik instruksional pada mahasiswa Prodi Teknologi Pendidikan. Peningkatan terlihat pada kategori baik mulai nampak pada siklus kedua. Mengacu pada data yang diperoleh pada siklus pertama, data hasil angket awal kemandirian belajar menunjukan persentase sebesar 39\% pada kategori sangat rendah, meningkat pada siklus pertama menjadi $60,5 \%$ pada kategori rendah, dan meningkat kembali pada siklus kedua menjadi $73 \%$ pada kategori tinggi. Data daya tarik instruksional berdasarkan hasil angket awal menunjukkan persentasi sebesar

Tabel 3. Skor Angket Kemandirian Belajar Siklus II

\begin{tabular}{lllll}
\hline No & \multicolumn{1}{c}{ Indikator } & Rerata Skor & \multicolumn{1}{c}{ Persentase } & Kategori \\
\hline $\mathbf{1}$ & Inisiatif & 33,8 & 72 & Tinggi \\
$\mathbf{2}$ & Percaya Diri & 33 & $71 \%$ & Tinggi \\
$\mathbf{3}$ & Tanggungjawab & 33,4 & $72 \%$ & Tinggi \\
$\mathbf{4}$ & Disiplin & 35,8 & $77 \%$ & Tinggi \\
\hline & Total skor & 34 & $73 \%$ & Tinggi \\
\hline
\end{tabular}

Tabel 4. Skor Angket Daya Tarik Instruksional Siklus II

\begin{tabular}{lllll}
\hline No & Indikator & Rerata Skor & Persentase & Kategori \\
\hline $\mathbf{1}$ & Penghargaan & 40,3 & $86 \%$ & Sangat Tinggi \\
$\mathbf{2}$ & Keinginan Lebih & 41,4 & $89 \%$ & Sangat Tinggi \\
\hline & Total skor & 41,85 & $87,5 \%$ & Sangat Tinggi \\
\hline
\end{tabular}

JURNAL PENELITIAN IIMU PENDIDIKAN, Volume 8, Nomor 2, September 2015 
$16 \%$ pada kategori sangat rendah, meningkat pada siklus pertama menunjukan persentase sebesar $61,5 \%$ pada kategori rendah, dan meningkat pada siklus kedua menunjukan persentase sebesar $87,5 \%$ pada kategori sangat tinggi.

Mengacu pada data yang telah dipaparkan sebagai bukti empiris adanya peningkatan baik pada siklus pertama maupun siklus kedua, maka dapat disimpulkan bahwa tindakan yang diterapkan dalam penelitian Prodi Teknologi Pendidikan dalam mata kuliah Pengembangan Multimedia Pembelajaran. Kesimpulan tersebut sejalan dengan pendapat $\mathrm{Nel}$ (2005:20) keuntungan menggunakan model blended learning adalah dapat mengakomodasi karakteristik matakuliah Multimedia Pembelajaran sehingga daya tarik instruksional perkuliahan menjadi tinggi, dan dapat mengembangankan berbagai keterampilan dan sikap, dalam hal ini kemandirian belajar.

\section{PENUTUP}

Berdasarkan hasil analisis data dan pembahasan dapat disimpulkan bahwa penggunaan model blended learning dapat meningkatkan kamandirian belajar dan daya tarik instruksional dalam perkuliahan mahasiswa Prodi TP FIP UNY dalam mata kuliah Pengembangan Multimedia Pembelajaran. Mengacu pada temuan penelitian ini disarankan bahwa: 1) model blended learning hendaknya diterapkan oleh para dosen dalam perkuliahan khususnya untuk meningkatkan kemandirian belajar dan daya tarik instruksional, dan 2) bagi peneliti lanjut, perlu meneliti apakah model blended learning juga dapat meningkatkan kemandirian belajar dan daya tarik instruksional diterapkan pada mata kuliah yang berbeda karakteristiknya.

\section{DAFTAR PUSTAKA}

Cheung, W. S., \& Hew, K. F. (2011). Desaign And Evaluation Of Two Blended Learning Approaches: Lessons Learned.
Australian Journal of Educational Technology, 8, 1319-1337.

Degeng, I.N.S. (1989). Ilmu Pengajaran Taksonomi Variabel. Jakarta: DebdikbudDikti.

------------ (2000). Paradigma Baru Pendidikan memasuki Era Demokratisasi Belajar. Makalah. Disajikan dalam Seminar dan Diskusi Panel Nasional Teknologi Pembelajaran V. 7 Oktober 2000 di UM, Malang.

Eti Nurhayati. (2011). Psikologi Pendidikan Inovatif. Yogyakarta: Pustaka Pelajar.

FIP UNY. (2009). Buku Kurikulum 2009. Yogyakarta: FIP UNY.

Griffith University. (2010). Getting Started with Blended Learning. Queensland: Griffith University.

Kemmis, S \& Taggart, Robin Mc. (1990). The Action Research Planner. Victoria: Deakin University.

Knowles, Malcolm, S. (1980). The Modern Practice of Adult Education From Pedagogy to Adragogy. New York: Cambridge.

Knowles, Macolm, S., Holton III, Elwood, F., \& Swanson, Richard, A. (2005). The Adult Learner. USA: Elsevier.

Littlejohn, Allison \& Pegler, Chris. (2007). Preparing for Blended E-learning. New York: Routledge.

Martinis Yamin. (2012). Desain Baru Pembelajaran Konstruktivistik. Jakarta: Referensi.

Nel, Elizabeth. (2005). Creating Meaningful Blended Learning Experiences In A South African Higher Education Classroom: An Action Inquiry. Bloemfontein: University of the Free State.

Uwes A. Chaeruman. (2011). Implementing Blended Learning: a Case Based Sharing Experience. Diambil dari http://www. teknologipendidikan.net/2011/06/21/ implementing-blended-learning-acase-based-sharing-experience/, pada 30 November 2012 pukul 16.35.

Yusufhadi Miarso. (2007). Menyemai Benih Teknologi Pendidikan. Jakarta: Kencana. 